\title{
Free Conversation: A Legitimate Use of Class Time?
}

\section{John Campbell-Larsen \\ Kyoto Women's University}

\section{Reference Data}

Campbell-Larsen, J. (2021). Free conversation: A legitimate use of class time? In P. Clements, R. Derrah, \& P. Ferguson (Eds.), Communities of teachers \& learners. JALT. https://doi.org/10.37546/ JALTPCP2020-31

The notion that interactional competence in the L2 emerges naturally once sufficient lexical/ grammatical knowledge is in place was disputed by Widdowson (1978), but this notion may still underlie some attitudes toward language learning in an institutional context. In this paper, I describe some central features of the genre of conversation and contrast these with the traditional interactional structures found in Japanese university classrooms. I suggest that the ability of learners to interact in the $\mathrm{L} 2$ requires both extensive opportunities for learners to engage in non-directed, phatic interactions supported by the teaching of interactional language skills. The approach may be initially challenging and confusing for learners, but over time, students align with the approach and interaction becomes smoother and more natural.

第二言語習得において、正確で高度な語彙と文法の知識が習得されれば相互行為能力は自然と身に付くものだと信じられ てきた。Widdowson（1978)により批判に晒された現在でも、この根拠のない神話は未だに現場に浸透し、言語学習の姿勢形 成に影響力を行使している感が否めない。本稿では、実際の学生の会話において話題・ジャンルの主要な特徴を記述し、日本 の大学において元来の教授法で実施されている会話と比較した。第二言語によるやりとりに必要とされる要素は、教師にお 眻立てされることなく交感的なやりとり参与する豊富な機会と明確な相互行為能力指導の一点である。当初はこの、教師にお アプローチに困或する学習者を生む場合もあるが、継続することで学生も徐々に適応し第一言語によるやりとりを元来の教 授法ではたどり着けないスムーズなものに変容させることができると考えられる。

lthough language textbooks and syllabi may refer to a four-skills balanced syllabus, A the situation in the classroom may be at odds with the way that language is used outside the classroom where the four skills are not equally balanced. The institutional needs of the SLA classroom, particularly in Japan, may privilege and emphasize the written form of the language, meaning that "...the spoken language has been downgraded and has come to be regarded as relatively inferior to written manifestations" (Carter, 2004, p. 26). This is despite the fact that speaking, mainly meaning quotidian social interaction or, simply, conversation, is the most frequent use of language in all societies. The focus on literacy-based teaching in Japan was highlighted by Osumi (2019) who reported a bias towards literacy skills and poor speaking test results among Japanese elementary and junior high school students.

The word free in the collocation free conversation may imply a general lack of structure and teachable rules. Similarly, the word conversation may conjure up notions of meaningless small talk. In the field of conversation analysis, Schegloff (2007) explicitly states that the term "talk-in-interaction" is used "so as to circumvent the connotation of triviality that has come to be associated with [conversation]" (p. xiii). These assumptions of triviality and formlessness are certainly not warranted, as conversation is a rulebound and orderly genre of speech. The rules and processes of conversation may not be intuitively accessible to teachers and thus conversation may be seen as difficult to teach and also to test. The intricate genre specifics of conversation and of teaching conversation must be acknowledged, but as Cook (1989) comments, "...if the difficulty with conversation classes is widespread, so too is the desire of students to converse successfully in the language they are learning." (p. 116).

\section{Teaching Speaking: The Japanese Context}

Even if some class time is given over to speaking, or indeed, if Japanese EFL students take a semester-long course with the title of Oral Communication, they may only have limited opportunities to actually produce spoken language. Additionally, the language that they may produce is often starkly prescribed in order to meet the institutional agenda of the teacher-for example, practicing a particular grammar form. Green (2016) notes, with reference to the Japanese context, 
...university entrance tests continue to emphasize the written language. Because they control access to opportunities, entrance tests tend to dominate teaching and learning. They are widely believed to encourage traditional forms of teaching and to inhibit speaking and listening activities in the classroom. (p. 135)

Furthermore, any speaking that the student does engage in will likely be seen as potentially subject to evaluation, often focusing on its formal morpho-syntactic correctness. Cutrone (2009, p. 60), notes for Japanese students that, "it is the evaluative environment that causes stress, not the content." Any morpho-syntactic error whatsoever may be subject to evaluation and repair, whether it was the lesson target or some other non-target item. For instance, it is easy to imagine a teacher initiating repair on a misused preposition in the student utterance, "The man met his friend on six o'clock," even if the ostensible target of the lesson is irregular past-tense verbs.

This kind of classroom exchange between teacher and student is described as the Initiation, Response, Feedback (IRF) sequence by Sinclair and Coulthard (1975), and it is probably fair to say that it is a highly salient feature of classroom interaction and one that most students commonly encounter in language classes and other lessons as well (see, for example the transcripts in Long \& Watanabe, 2021, which adhere to the IRF format). There may also be unintended results of the frequent recourse to IRF sequences. The question-followed-by-answer sequence is probably one of the most readily identifiable adjacency pairs (Sacks et al., 1974). In the IRF sequence, the student is habitually placed in the second slot. That is, students may become used to producing utterances only on demand and may find it difficult to do so outside of this framework. In addition, the content of the response turn is usually seen as being acceptable in its minimized form.

That is, the content of the response answers the teacher's question in fairly narrow terms and both the content and the form of the turn are understood to be subject to evaluation in the third turn-the F of the IRF sequence.

A further outcome of organizing talk along IRF lines is the tendency for IRF sequences to appear adjacently. That is, once an IRF sequence has finished, another sequence is initiated by the teacher and this sequence may be directed at another student to fill the R slot. If it is directed at the same student, the sequence may either be minimally connected to what went before, or the question may be completely topically unrelated to the previous sequence - i.e., it may be the next question in the book that does not pick up on or develop what was produced by the student in the previous sequence. For examples of the kinds of minimalized and jejune speaking that seems based on an orientation to IRF sequences, with minimal or no uptake of the content for development of progressivity, see the transcripts of student talk in Campbell-Larsen (2014, 2019).

\section{Genres of Speech}

Just as teaching a course in creative writing will not enable students to transfer writing skills to the writing of an academic paper, so will a presentation class or extensive practice for an oral proficiency interview not automatically enable learners to engage in conversation. In order to teach conversation, the teacher must understand the genre of conversation and how this genre differs from other genres of speech. Cook (1989, p. 51) describes the central features of conversation thus:

1. It is not primarily necessitated by a practical task

2. Any unequal power of participants is partially suspended

3. The number of participants is small

4. Turns are quite short

5. Talk is primarily for the participants and not for an outside audience.

I will take these in order and suggest that classroom talk (mainly the IRF sequence, but also other kinds of talk such as pair work and task-based learning) is at variance with these features.

Premise 1 . The classroom is seen as a place where learning takes place, and by learning what is most commonly meant is a change in learners' epistemic status from $\mathrm{K}$ - (unknowing) to $\mathrm{K}+$ (knowing), usually referring to lexico-grammatical items. The knowledge that is imparted to students is predetermined, concrete, and testable. Therefore, speaking that takes place without aligning to this agenda may be deemed illegitimate as a classroom activity. Classroom talk is therefore necessitated by the overt task of language learning.

Premise 2 . In any classroom there is usually a clear power differential between the teacher and the students. Student talk is accessible to the teacher, who has the power to ratify and sanction all occurrences of talk. Students do not usually have the right of non-participation, which is available to conversational participants in mundane social interactions.

Premise 3. The number of participants can vary widely in the language class. In teacher-fronted lesson segments, the participatory framework can involve dozens of ratified participants, with the teacher as pivot i.e., one primary speaker who occupies a central role and administers turns in a reworking of some aspects of the teacher's role (Hauser, 2009). and the non-nominated students being in a passive, but still participatory role. In group work, the number of participants may be small, but learners may avoid the 
natural tendency to schism (Egbert, 1997) and instead orient to a turn taking system that revolves around the pivot. Alternatively, speakers may orient to a turn taking system that proceeds in strict order "around the circle".

Premise 4. Turns are short in mundane conversation (for empirical data, see Rühlemann, 2018), but not uniformly so. A series of minimized turns, often single-word and single-phrase responses to questions, quickly makes the interaction burdensome.

Premise 5. Classroom talk is ideally supposed to be aligned with the institutional agenda of language learning, with the teacher being the sole arbiter of what kind of talk takes place. In a teacher-fronted classroom, in a dyadic exchange between the teacher and a nominated student, (i.e., an IRF sequence), the exchange is in public and on record and tacitly includes the other students as ratified overhearers. (Goffman, 1981). The exchange, in addition to being between the teacher and the student, is seen as being for the benefit of the overhearing students, who are expected to listen to the exchange for the purposes of language learning.

In pair and group work, talk unfolds between students with varying degrees of teacher monitoring. Once the task or activity is completed, there will likely be a return to a teacher-fronted participant framework, and the students can expect to be called on to reveal the outcome of their talk in front of the whole class, for evaluation by the teacher and as a learning opportunity for other students. Thus, classroom talk, either between teacher and student or between student and student, is usually seen as being partly or wholly for non-participants, be it the teacher or the other students, either during the moment of utterance or in a subsequent lesson phase.

\section{Constraints on Communication}

In addition to the above points, it is also worthwhile considering the ways in which even the most "communicative" of speaking activities unfolds and compare these with the ways in which conversation in its basic, non-instructional form takes place. In my experience of observing classrooms in junior high schools, high schools, and university contexts in Japan, student speaking in a typical group or pair work activity may be subject to the following constraints:

- The teacher allocates a topic or task. Students have little or no say in this.

- It is tacitly assumed that the students will align with this topic and not depart from

- The teacher may allocate group membership. The students align with whatever grouping the teacher decides. All group members are expected to contribute equally.

- The teacher overtly signals the onset of the talk, even though he/she is a nonparticipant.

- The teacher may set a time limit for the talk. If students finish before the allotted time, other, non-topic, talk may be stopped by the teacher. If students have not finished by the allotted time, they may appeal for more time, but the teacher is the arbiter of this.

- The teacher usually signals the end of the speaking activity, often aligning with concerns such as the lesson plan, or class timing, rather than the actual speaking that is in progress.

Here it is clear that even if the students are engaged and motivated, the classroom group/ pair activity inherently deprives them of agency in many areas where agency is normally found. Conversation is a spontaneous activity and participants in conversation have to be proactive in real time about things like topic nomination, progressivity, development (Wong \& Waring, 2020), and participant inclusion (Campbell-Larsen, 2020). In conversations, all members may be ratified participants, or schisms may occur in groups of more than three members and smaller groups form automatically and tacitly. The onset of the talk happens by mutual agreement among the pre-present members, and not in response to an overt signal from a non-participant. Participation may be unequal, with speakership aligning to the wishes and desires of the participants themselves and the option of non-participation being available to any person. Topics constantly drift and recycle. That is, talk is never mono-topical for long and the process of stepwise transition means that participants often move through several topics without any apparent, overt topic disjuncts (Jefferson, 1984). Not all conversations have a limited time allocation set in advance though. They may be very brief or extremely lengthy, depending on objective and subjective criteria. Similarly, not all conversations have fixed participant numbers; participants may enter and leave (and return) over the course of an extended interaction.

In contrast to this the classroom group/pair activity is subject to an institutional interactional architecture (Seedhouse, 2004) and within this participation framework it is tacitly assumed that "as a means to attaining their goals, the teachers put constraints on their students' participation rights and restrict what is considered acceptable contributions to the discourse." (Hellman, 2019, p. 24). This may find expression in the following unspoken imperatives that can apply to a typical speaking exercise: 
- Speak. Do not remain silent.

- Speak to the people I tell you to speak to, and only those people.

- Speak on the topic/task I nominate and no other topic/task.

- Start speaking when I tell you to start speaking.

- Stop speaking when I tell you to stop speaking.

The result is that many students, in my experience, often find it difficult to engage in speaking that is not recognizably aligned with the kinds of classroom interaction outlined above. When the teacher gives free time to students, instructing them to use the time to talk in English as much as possible, the following behaviors, especially in the early stages, are recurrent:

- Silence, often accounted for by statements that "we have no topic" and the like.

- Requests for the teacher to provide a topic or task.

- Formation of large groups and avoidance of schisming.

- Short question and answer sequences on a small number of recurrent topics such as weekend activities, holiday plans and sports.

- Reversion to L1.

- Frequent abrupt topic changes.

- Difficulty in sustaining interaction for more than a few minutes.

(For transcripts, see Campbell-Larsen, 2019.)

\section{Beyond the IRF Sequence: Creating a Space for Free Conversation}

If teachers take seriously the task of enabling learners to participate in spontaneous multi-party spoken interaction (conversation), then students must be fully aware of the purpose of any classroom activity that pursues this goal. The nature of the genre of conversation, as outlined above, must be communicated to the learners by whatever means are effective. It must also be communicated to students that the success or failure of such a classroom enterprise is primarily the responsibility of the learners and cannot rely on teacher support and scaffolding. At the outset of the course, the way in which the conversation phase of teaching will proceed must be explicitly stated and concept checked. In my classes, this phase of teaching is referred to as student talk time (STT). The key features of STT are as follows:
- STT is a recurrent feature of every class.

- STT occurs for an extended period every time. That is, it will go beyond a few minutes of "How was your weekend?"-style Q\&A exchanges.

- The transition into STT is minimally marked. That is, the teacher gives no overt signal to start talking. The STT usually takes place at the beginning of the class, immediately after administrative duties such as taking the register. The teacher then falls silent and moves away from the front of the classroom. Students then orient to what speakers in any social situation do and fill silence with talk.

- The learners have complete autonomy in matters of group selection, topic choice and topic maintenance and some autonomy in terms of participation.

- No handouts, flashcards, exercises or other supporting materials are provided by the teacher.

- The talk takes place in English as much as possible, as decided by the students.

- There is no sanction on use of the L1.

- The teacher may move around the class and join groups as a participant or may monitor from a distance.

- The students have the right to refuse the teacher's participation, citing privacy or other reasons.

- Local and episodic non-participation is allowed, but serial non-participation is treated as absence with concomitant effects on grading.

- The end of STT is open to negotiation. If students wish to continue talking, they can ask to do so.

In support of the STT phase, weekly lesson targets often focus on key interactional skills such as turn-taking procedures, discourse marker use, repair strategies, and effective backchanneling.

\section{Free Conversation in Action}

Many learners in the Japanese university context initially find the concept of free conversation in English during class time to be confusing and challenging. In my experience, they may see it as teacher laziness or not proper teaching (see the student transcript in the next section). The early stages of implementing a free conversation section in class may be met with resistance, silence, fairly swift abandonment of any 
pretense of speaking in English, and continuation of the conversation in the L1. However, after this initial phase of uncertainty and chaos, in my experience, there is a gradually emerging orientation to the activity. Students, faced with the choice of traditional and familiar classroom activities or the option to use the $\mathrm{L} 2$ with much less at stake and lower levels of anxiety, start to participate more willingly. It is as if they cross a psychological boundary where they reconfigure their identities as English learners to that of English users. That is, they use all of their English abilities to jointly create meaning with co-participants instead of only producing language on demand that is wholly subject to narrow evaluations.

\section{Student Reactions to Free Conversation}

According to informal data I have collected, students generally react positively to the STT phase of lessons, once it has become an established part of the weekly or bi/triweekly lesson. In questionnaires administered each week to a class of second year English majors, students were asked to evaluate their own language use. At the beginning of the semester most students self-assessed their talking as being approximately 60 percent in English and 40 percent in Japanese. As the semester progressed the weekly selfevaluations showed a general increase and by the semester end, the majority of students were self-assessing their speaking at 70-80 percent in English with a concomitant reduction in the amount of Japanese language use. The rate was not steady, and in some weeks students self-reported lower amounts of English use. No sanction or criticism was given for this falling back and students were encouraged to reflect on their performance differentials. Over the course of the semester, the pattern was generally towards increased English use.

In these weekly questionnaires, the students self-reported development in things like discourse marker (DM) use. In the initial stages DMs were largely absent from learner talk, but most learners self-reported increased use of these key fluency indicators as the semester progressed. This data was confirmed by focused teacher monitoring (both as a participant and ratified overhearer) of DM use in student conversations. Supporting the STT phase with explicit teaching (and reviewing) of interactional aspects of language proficiency is a very important feature of this approach. That is, STT cannot be conducted as a stand-alone phase, with the rest of the class time devoted to traditional, grammar and vocabulary targets suitable for the completion of standardized written tests. For qualitative data regarding the development of interactional speaking skills, see Campbell-Larsen (2019).
Furthermore, I also noticed that the volume (loudness) of talk gradually increased over the course of the semester, with laugher and other paralinguistic features becoming commonplace. One of the strongest indicators of the reconfiguration of the classroom and teacher/student relationship was the students occasionally refusing the teacher's right to participate in an ongoing interaction citing "girls'/boys' talk" and privacy. My observations confirmed that the students in these cases were speaking mostly in English.

Comments to the teacher in private, and on the above-mentioned weekly surveys, and also student responses on official, institutional surveys consistently included positive comments on the use of class time for free conversation. The following are excerpts from a transcript from a student who gave informed consent within university guidelines to be interviewed and recorded talking about the STT lesson format. The transcript has not been edited for errors in order to reflect the student's level of spoken English (S=student; $\mathrm{T}=$ teacher).

S: You gave us at the beginning of the class, we have 20 minutes to talk about whatever we want.

T: Right

S: And at first, I thought it's just wasting a time. Because we pay for class, to come to this university, but you just give us a time, just talk and say what you want. Why you do that and what's the purpose of it?

T: Did you feel like I was being a bit lazy?

S: Kind of

T: It's okay, be honest.

S: Actually, I thought, "Yes." But after a couple of months later I thought, "Oh, I just speak more natural. I don't have any trouble to think. Just we can talk."

T: Uh huh $[\ldots]$

S: I thought having a conversation is not only speaking, it's also improve my listening ability too. Then I thought, "Oh, I should talk more active in the classroom. It's not just wasting a time. It's also give us a really efficient way to improve our (inaudible)." [...] And also, it's not just like a writing conversation, I mean, not only textbook.

T: No, no. 
S: It’s like, "Right," or "I see." It’s like, you know, discourse. We can improve how to behave in a conversation.

[...]

T: So finally, you think, like, it's a useful way to spend class time?

S: Yes, yes.

This transcript is illustrative of the general view among students, expressed in a variety of media, that free conversation is a legitimate use of class time.

\section{Conclusion}

$\mathrm{I}$ argue in this paper that knowing how to have a conversation is not a necessary and sufficient condition for having a conversation in an $\mathrm{L} 2$, and the only real way to become better at conversation is to converse. Wong and Waring (2020, p. 1) state, "The importance of conversation as the foundation of all language teaching cannot be overstated." With this in mind I have sought to describe what conversation is-and by implication what it is not. Talk supported by tasks, worksheets, handouts and the like may produce a simulacrum of conversation, but the talk thus produced is not conversation in the strict sense of the word. I have suggested the need for teachers to fully understand the implications of this and also described some of the ways a free conversation program may unfold over time.

Free conversation in class time is challenging for a number of reasons. The practice may be contrary to deeply held beliefs (on the part of students and teachers alike) concerning what can and should happen in the institutional activity of a language lesson. The genre of conversation must be understood and seen as rule-bound and orderly. The ways in which the conversation genre differs from other speech genres, especially classroom discourse, must be understood clearly by the teacher and this must be communicated effectively to students. The use of class time for free conversation should be supported by explicit teaching of conversational practices.

Further research is needed concerning issues such as age and level of students, class size, frequency of lessons and the length of STT phase, to determine boundaries for the efficacy of this kind of classroom activity. Similarly, longitudinal studies focused on single issues, such as turn-taking practices or participation frameworks in triadic interactions, may yield insights into student talk outside the IRF framework.

\section{Bio Data}

John Campbell-Larsen is a professor in the Department of English Studies, Kyoto Women's University. He is interested in cognitive linguistics, pragmatics, conversation analysis, and teaching spoken English. <joncamlar@hotmail.com>

\section{References}

Campbell-Larsen, J. (2014). Disfluency: An opposite or an absence? In N. Sonoda \& A. Krause (Eds.), JALT 2013 Conference Proceedings (pp 1-11). JALT.

Campbell-Larsen, J. (2019). From needs analysis to emergent pragmatic competence: A longitudinal micro-analytic study of learner talk in Japanese EFL university classes. In L.U. Takeda \& M. Okuguri (Eds.), A pragmatic approach to English language teaching and production (pp. 169 -197). Kazama Shobo.

Campbell-Larsen, J. (2020). Entering an ongoing conversation. In J. Talandis Jr., J. Ronald, D. Fujimoto, \& N. Ishihara (Eds.), Pragmatics undercover: The search for natural talk in EFL textbooks (pp. 58-63). JALT.

Carter, R. (2004). Grammar and spoken English. In C. Coffin, A. Hewings, \& K. O’Halloran, (Eds.), Applying English grammar: Functional and corpus approaches (pp. 25-39). Routledge.

Cook, G. (1989). Discourse. Oxford University Press.

Cutrone, P. (2009). Overcoming Japanese EFL learners' fear of speaking. Language Studies Working Papers, 1, 55-63. Retrieved from http://www.reading.ac.uk/web/files/english-language-andliterature/ell_language_Cutrone_vol_1.pdf

Egbert, M. M. (1997). Schisming: The collaborative transformation from a single conversation to multiple conversations. Research on Language and Social Interaction, 30(1), 1-51. https://doi. org/10.1207/s15327973rlsi3001_1

Goffman, E. (1981). Forms of talk. University of Pennsylvania Press.

Green, A. (2016). Testing Four Skills in Japan. British Council New Directions in Language Assessment. JASELE Journal Special Edition, 135-144. Retrieved from https://core.ac.uk/ download/pdf/77038094.pdf

Hauser, E. (2009). Turn-taking and primary speakership during a student discussion. In H. thi Nguyen \& G. Kasper (Eds.), Talk-in-interaction: Multilingual perspectives (pp. 215-244). National Foreign Language Resource Center.

Hellman, S. (2019). Power asymmetry in classroom discourse: A study of turn-taking systems in teacher-student interaction. (Dissertation). Retrieved from http://urn.kb.se/resolve?urn=urn:nbn :se:sh:diva-38460</div>

$</$ div $>$ 


\section{JALT2020}

COMMUNITIES OF
TEACHERS \& IEARNERS

Jefferson, G. (1984). On stepwise transition from talk about troubles to inappropriately next-

positioned matters. In J. M. Atkinson \& J. Heritage (Eds.), Structures of social action (pp. 191-222).

Cambridge University Press.

Long, R., \& Watanabe, H. (2021) The Mirage of Progress? A Longitudinal Study of Japanese Students' L2 Oral Grammar. The Language Teacher, 45(2), 9-14. https://doi.org/10.37546/ JALTTLT45.2

Osumi, M. (2019). Nationwide test results highlight Japanese students' poor English speaking and writing skills. The Japan Times. Available from https://www.japantimes.co.jp/ news/2019/08/01/ national/nationwide-test-results- highlight-japanese-students-poor-english-speaking- writingskills/\#.XdOaGy-B3Hc

Rühlemann, C. (2018). Corpus linguistics for pragmatics: A guide for research. Routledge.

Sacks, H., Schegloff, E.A., \& Jefferson, G. (1974). A Simplest Systematics for the Organization of Turn Taking for Conversation. Language 50(4), 696-735. Retrieved from https://pure.mpg.de/ rest/items/item_2376846/component/file_2376845/content

Schegloff, E. A. (2007). Sequence organization in interaction: A primer in conversation analysis. Cambridge University Press.

Seedhouse, P. (2004). The interactional architecture of the language classroom: A conversation analysis perspective. Blackwell.

Sinclair, J. M., \& Coulthard, R. M. (1975). The English used by teachers and pupils. Oxford University Press.

Widdowson, H. G. (1978). Teaching language as communication. Oxford University Press.

Wong, J., \& Waring, H. Z. (2020). Conversation analysis and second language pedagogy: A guide for ESL/EFL teachers. Routledge. 